\title{
Environmental Impact Assessment of Soil Pollution in Industrial Zones
}

\author{
Salim Rabee Znad*, Mazin Nazar Fadhel \\ Department of Environmental Sciences, College of Environmental Sciences and Technology, University of Mosul, Mosul, Iraq
}

Email address:

Salim.znad@yahoo.com (S. R. Znad)

${ }^{*}$ Corresponding author

\section{To cite this article:}

Salim Rabee Znad, Mazin Nazar Fadhel. Environmental Impact Assessment of Soil Pollution in Industrial Zones. International Journal of Environmental Monitoring and Analysis. Special Issue: Environmental Impact Assessment of Pollution. Vol. 8, No. 6, 2020 , pp. $193-201$. doi: $10.11648 /$ j.ijema.20200806.13

Received: October 16, 2020; Accepted: November 11, 2020; Published: November 23, 2020

\begin{abstract}
The study area is the city of Mosul, which is located in the north-western part of Iraq and study aims to determine the level of heavy metal contamination in the main industrial areas of Mosul City, northern Iraq, where 12 samples collected Only soil samples had been collected with depth $(0-15) \mathrm{cm}$ by using a homemade soil sampler in industrial zone. Samples was carried in January 2019. First of all, samples were air-dried in natural condition, and the debris of animals and plants had been cleaning by hands. Samples grind and pass through a sieve $(2 \mathrm{~mm})$, so they ready to measure. and analyzed from the industrial soil areas (6 samples from the soil of the Okab industry- west of Mosul City) and (6 samples from the soil of the Karama Industry-East of Mosul City), the soil was at depth $(0-15) \mathrm{cm}$ and analyzed by the X-ray Fluorescence for 8 metals included $(\mathrm{Pb}, \mathrm{As}, \mathrm{Cd}, \mathrm{Ni}, \mathrm{Cr}$,). The GIS10.6.1 ArcMap program was used to draw the environmental maps of each metals and to determine the extent of these metals and their impact on neighboring regions The results obtained for heavy metals and compared to the WHO, 2003 and these areas are already contaminated with (Ni, Cr, As) metals that have Exceeded the specified values. In addition, $\mathrm{Pb}$ and $\mathrm{Cd}$ elements are within the allowed values.
\end{abstract}

Keywords: Assessment, Industrial Pollution, GIS10.6.1 ArcMap Program

\section{Introduction}

The problem of pollution is one of the most pressing environmental problems that are beginning to take on serious environmental dimensions, especially after the Industrial Revolution, technological progress and the use of modern methods in industry [1].

One of these very serious environmental problems is heavy metal pollution that accumulates in the environment as a result of human activities and includes some biological toxicity metals $(\mathrm{Hg}, \mathrm{Cd}, \mathrm{Pb}, \mathrm{Cr}, \mathrm{As})$. As the development of the global economy has increased, the content of these metals in the soil has gradually increased as a result of various human processes and activities [15].

The increased concentration of heavy metals in various sources is given much attention of interest, especially as many industries are offering their own the container on heavy elements is untreated. [6]

Heavy metals can have serious health effects with Various symptoms depending on the nature and quantity of the swallowed element. [2]

Heavy metals are among the most dangerous non-organic pollutants on the environment Health because it cannot be physiologically immoral. [11]

The World Health Organization (WHO) has confirmed that some heavy metals, particularly lead, cadmium and nickel, have the ability to accumulate in various human organs with high-toxicity concentration. [14] Long-term exposure of heavy metals causes serious damage and kidney failure, causing blood disease, anemia and brain damage. [16]

Heavy metals are used in a large number of applications for their excellent physical and chemical properties, which are a good connection to heat and electric current, and their colorful compounds are highly-evidential and are not quickly influenced by atmospheric factors and most of them are road, draw, and shape. [8]

Soil contamination occurs when chemicals are released by spillage or underground leakage, with heavy metals being the 
most important soil pollutants, including herbicides, hydrocarbons, chemicals, salts, and radioactive substances, having adverse effects on plant growth, animal health, and human health. [13]

12 sample river sediments were analyzed by the X-ray Fluorescence ( $\mathrm{Fe}, \mathrm{Cu}, \mathrm{Zn}, \mathrm{Pb}, \mathrm{As})$ and the use of the enrichment index (EF) and Geographic Accumulation Index (Igeo) to assess human impact quantitatively. [9]

In addition, other researchers such as Bing Chen and others have studied about Size distribution and concentration of heavy metals in aerosols origin from industrial emissions as prewritten by the hydroplit model; 2013) Heavy metals, their movement, their septicullance and metals $(\mathrm{Cr}, \mathrm{Co}, \mathrm{Ni}$, $\mathrm{La}, \mathrm{Zn}, \mathrm{Mo}$ ) were described as pollution caused by industrial emissions in the area. [4]

It was also carried out in a study by M.chakravarty and others about (Metal polynomial assessment in segment of the
Dikong River, N. E. India; 2009). The 9 metals are (Al, Fe, $\mathrm{Ti}, \mathrm{Mn}, \mathrm{Zn}, \mathrm{Cu}, \mathrm{Cr}, \mathrm{Ni}, \mathrm{Pb}$ ) where the (ER) indicator is used and The pollution Load Index (PIL) and Geographic accumulation Index (Igeo) have revealed that pollution has resulted from $\mathrm{Pb}$ sediments, $\mathrm{Cu}$. [12]

It was therefore necessary to carry out an assessment of the pollution produced by industrial zones and to know the extent of the threat to the environment.

\section{Background and Sample Collection}

The study area is the city of Mosul, which is located in the north-western part of Iraq, between the longitude of $41^{\circ}-44^{\circ}$ and the latitude of $35^{\circ}-37^{\circ}$. In particular, the two main industrial areas of the city are the manufacture of the Okab on the right side (the western part) and the Karama on the left side (the eastern part) (Figure 1).

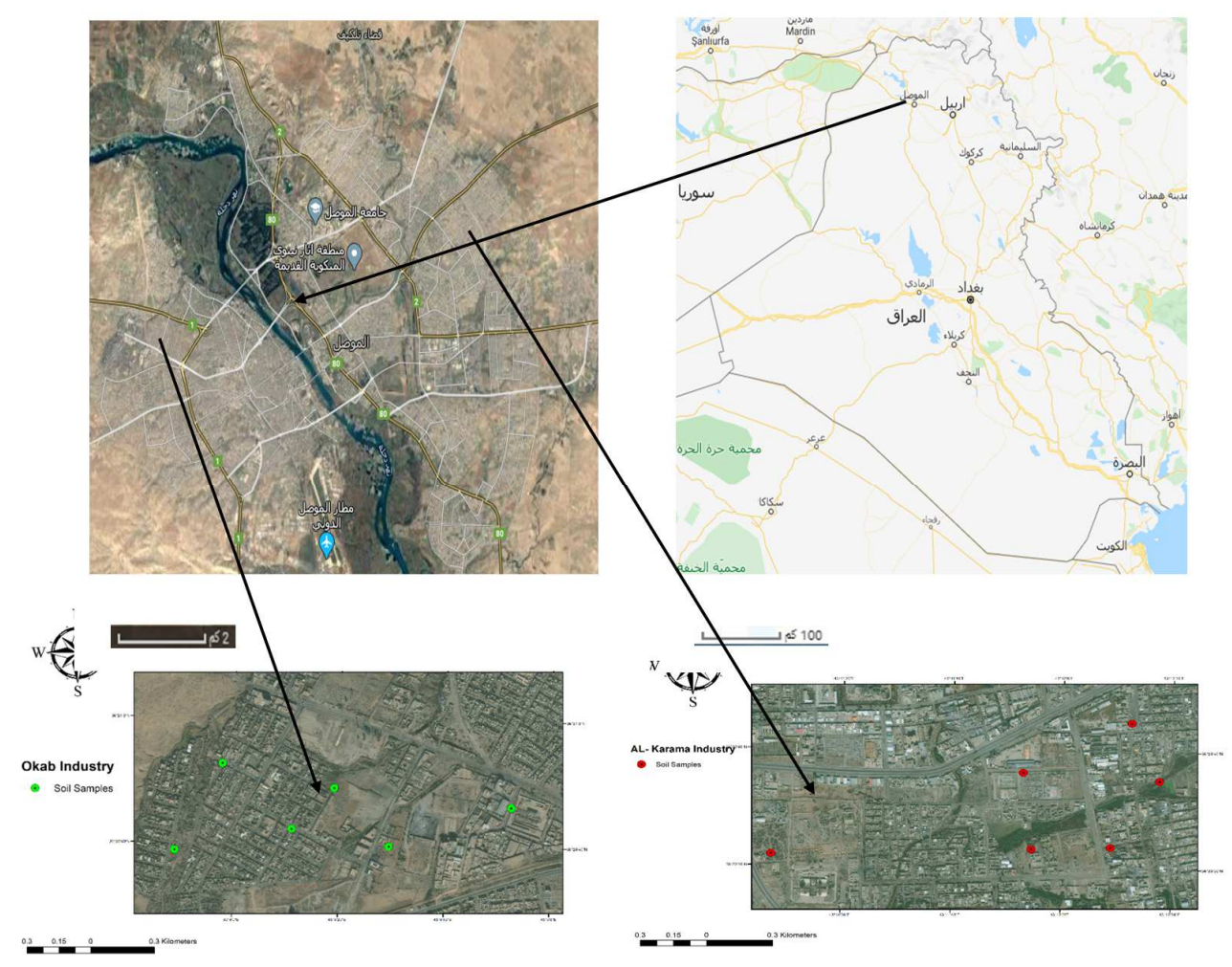

Figure 1. Location of Study Area.

\section{Sampling}

Only soil samples had been collected with depth $(0-15) \mathrm{cm}$ by using a homemade soil sampler. A total of 12 surface had been collected at industrial zone. Samples was carried in January 2019. First of all, samples were air-dried in natural condition, and the debris of animals and plants had been cleaning by hands. Samples grind and pass through a sieve ( $2 \mathrm{~mm})$, so they ready to measure.

Analysis of samples: after collecting samples they analyzed by X-Ray Fluorescence, SPECTRO XEPOS from AMETEK. (XRF) method was great used for monitoring the concentration of metals. Using GIS10.6.1 ArcMap program to Monitors, distributes these metals.

\section{Result and Discussion}

The degree of soil contamination with heavy metals is a measure that identifies environmental pollution as the increase in heavy metal barges causes serious damage to the soil, while the decrease in these minerals causes serious human health complications as the decrease in copper and manganese elements leads to human heart disease. [10]

Table 1 shows the heavy metals of the Karama Industry Area and at a depth of $0-15 \mathrm{~cm}$. The table 2 shows the heavy metals of the Okab Industry Area and at a depth (0-15) cm.

The results obtained were compared with the WHO, 2003 Handbook. [17] Table 3 shows the heavy metals determinants 
in soil.

Table 1. Heavy metals of soil samples the area of the Karama industry in unit (ppm).

\begin{tabular}{llllllll}
\hline $\mathbf{C r}$ & $\mathbf{N i}$ & $\mathbf{C d}$ & As & Pb & Depth $(\mathbf{c m})$ & No. & Study of Aerea \\
\hline 50.22 & 187.9 & 0.03 & 0.00 & 0.40 & $15-0$ & $\mathrm{Li} 1$ & \\
54.40 & 217.40 & 0.04 & 10.23 & 0.37 & $15-0$ & $\mathrm{Li} 2$ & \\
47.30 & 207.60 & 0.02 & 0.00 & 0.33 & $15-0$ & $\mathrm{Li} 3$ & Al-Karama Industry \\
43.30 & 140.5 & 0.05 & 0.00 & 0.30 & $15-0$ & $\mathrm{Li} 4$ & \\
45.50 & 155.30 & 0.05 & 2.30 & 0.25 & $15-0$ & $\mathrm{Li} 5$ & \\
53.40 & 117.33 & 0.06 & 1.20 & 0.22 & $15-0$ & $\mathrm{Li} 6$ & \\
\hline
\end{tabular}

Table 2. Heavy metals of soil samples the area of the Okab industry in unit (ppm).

\begin{tabular}{llllllll}
\hline $\mathbf{C r}$ & $\mathbf{N i}$ & $\mathbf{C d}$ & $\mathbf{A s}$ & $\mathbf{P b}$ & Depth $(\mathbf{c m})$ & No. & Study of Aerea \\
\hline 82.15 & 144.22 & 0.02 & 7.24 & 0.96 & $15-0$ & $\mathrm{Ri} 1$ & \\
133.43 & 227.34 & 0.01 & 7.33 & 0.7 & $15-0$ & $\mathrm{Ri} 2$ & \\
77.32 & 154.11 & 0.03 & 5.21 & 1.17 & $15-0$ & $\mathrm{Ri} 3$ & \\
87.32 & 150.87 & 0.01 & 0.73 & 1.12 & $15-0$ & $\mathrm{Ri} 4$ & Okab Industry \\
288.21 & 128.54 & 0.03 & 0.09 & 2.93 & $15-0$ & $\mathrm{Ri} 5$ & \\
102.32 & 90.65 & 0 & 0.011 & 0.87 & $15-0$ & $\mathrm{Ri} 6$ & \\
\hline
\end{tabular}

Table 3. The specific values for concentration of heavy metals in the soil. WHO, 2003 (ppm).

\begin{tabular}{ll}
\hline standard & specified value \\
\hline $\mathrm{Cd}$ & $1-3$ \\
$\mathrm{Ni}$ & $30-75$ \\
$\mathrm{~Pb}$ & $50-300$ \\
$\mathrm{Cr}$ & $1-5$ \\
\hline
\end{tabular}

Lead $(\mathrm{Pb})$

The results in a table 1 showed that the lead metal values in the soil of the Karama Industry ranged between (0.22$0.40)$ ppm.

The lead component values in this region are lower than the World Health Organization (WHO), 2003 is $50 \mathrm{ppm}$ global determinants. The maps obtained by GIS10.6.1 show the distribution of lead Concentration in the surface of the Karama Industry Area Figure 2. Maps show a clear increase in lead in areas near replacement stores for the batteries of the Hat cars and plastic recycling laboratories containing lead in their waste.
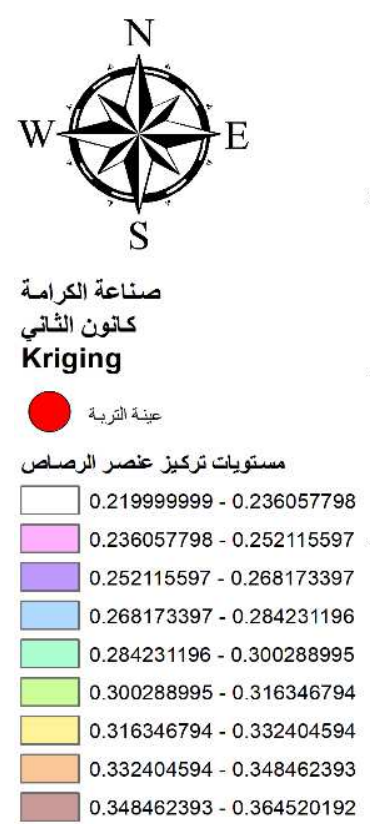
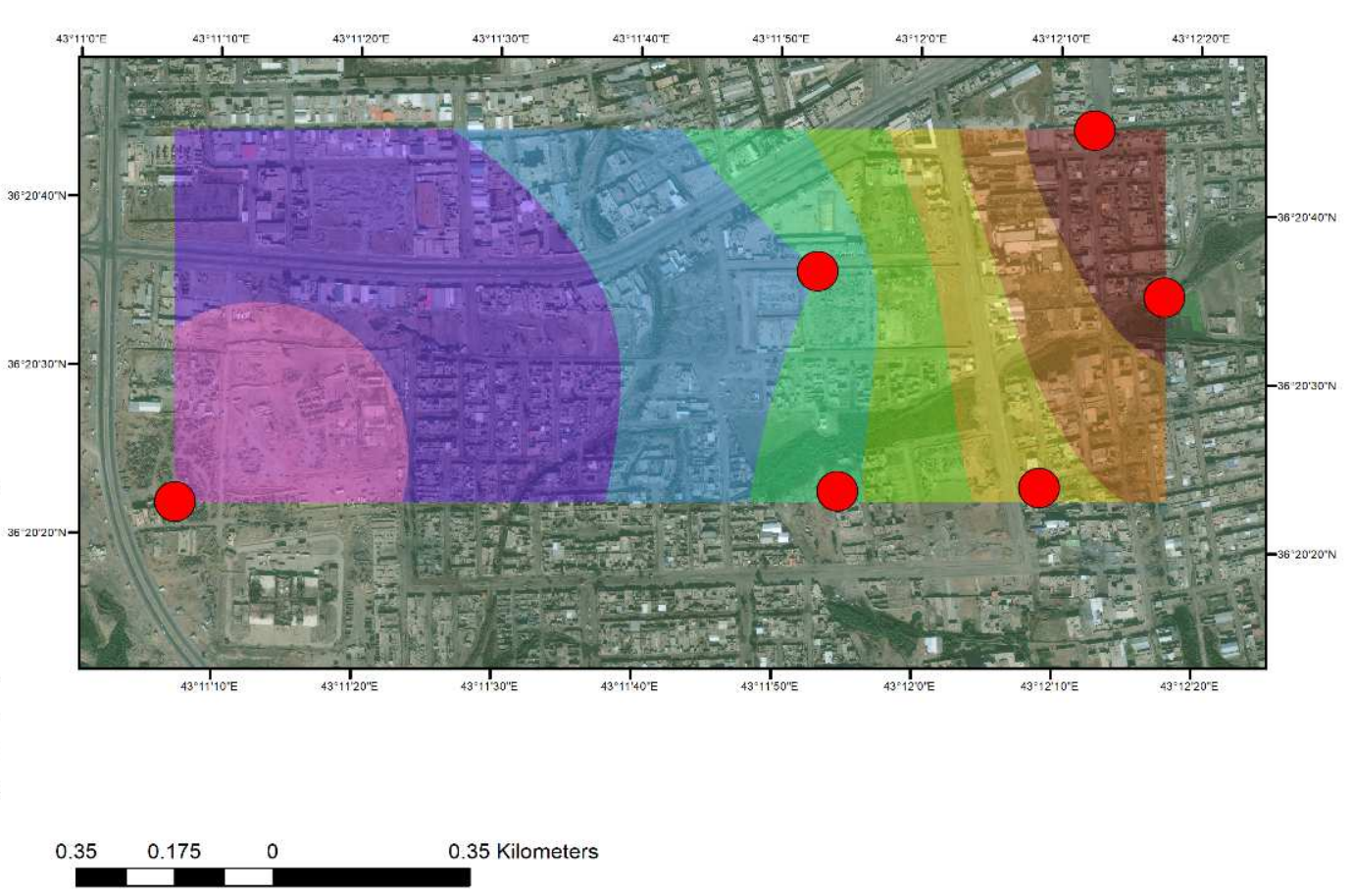

Figure 2. Shows the distribution of lead in the soil of the Karama industry.
The results in a table 2 showed that the lead metal values in the soil of the Okab Industry ranged between (0.7-2.93) ppm. The lead component values in this region are lower than the World Health Organization (WHO), 2003 is 50 ppm global determinants. The maps obtained by GIS10.6.1 show the distribution of lead concentration in the surface of the Okab Industry Area Figure 3. The maps show a clear increase of metal in the areas near the remains of the car swarms that were exposed to bombardment during the last war on Mosul city and the areas that were exposed to bombardment. 

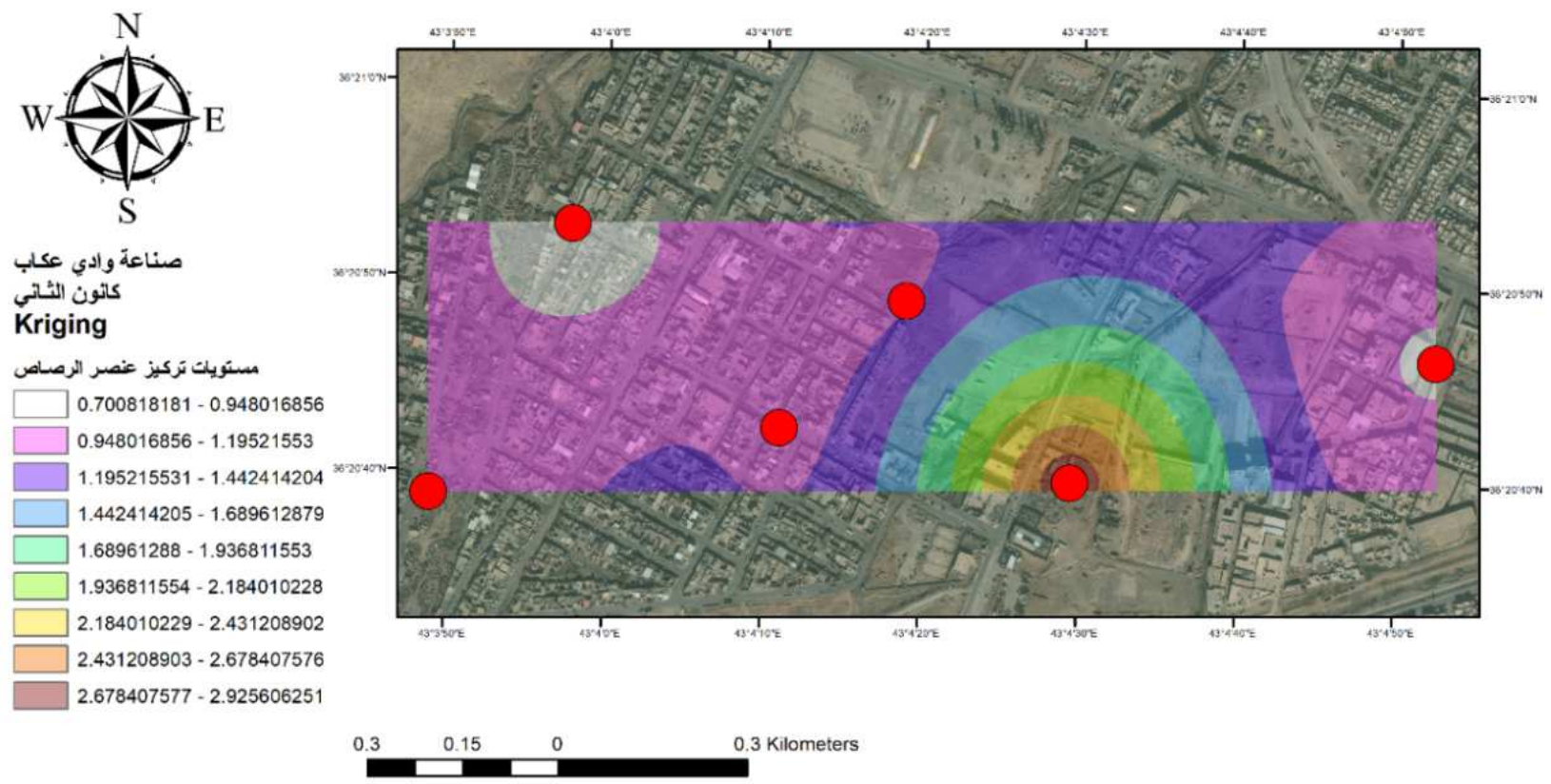

Figure 3. Shows the distribution of lead in the soil of the Okab industry.

\section{Arsenic (As)}

The arsenic metal is widely distributed among great and different types of minerals in Earth's crust and has a value of $2 \mathrm{ppm}$. It is found in rocks at (1 - 3) ppm and sediments rock $(1-25) \mathrm{ppm}$ and is usually found in high concentration of up to $400 \mathrm{ppm}$ and above arsenic is present in most soil at (0.140) $\mathrm{ppm}$. Where arsenic enters the surrounding environment in the form of arsenic oxide, which is more toxic. [5]
The results in a table 1 showed that the Arsenic metal values in the soil of the Al-karama Industry ranged between (0-10.23) ppm. The maps obtained by GIS10.6.1 show the distribution of the arsenic metal of the surface of the Karama Industry Figure 4. Maps show a clear increase in arsenic in areas close to carving workshops and wood laboratories containing arsenic in their wastes.
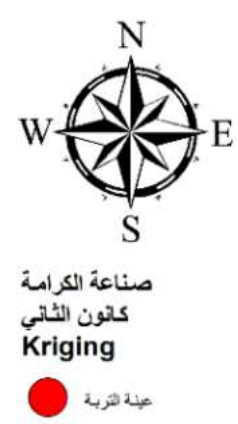

مستويت تركيز عنصر الززنبغ

$0.011599808-1.143141242$

$1.143141243-2.274682677$ $2.274682678-3.406224111$ $3.406224112 \cdot 4.537765545$ $4.537765546-5.66930698$ $5.669306981-6.800848414$ $6.800848415-7.932389849$ $7.93238985-9.063931283$ $9.063931284-10.19547272$

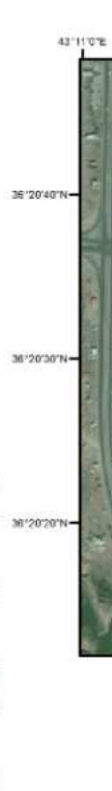

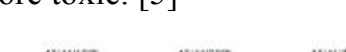


areas close to the remains of the car swarms that were bombed during the last war in the city, as well as the buildings that were bombed, indicating that the ammunition used contained arsenic in its installation.
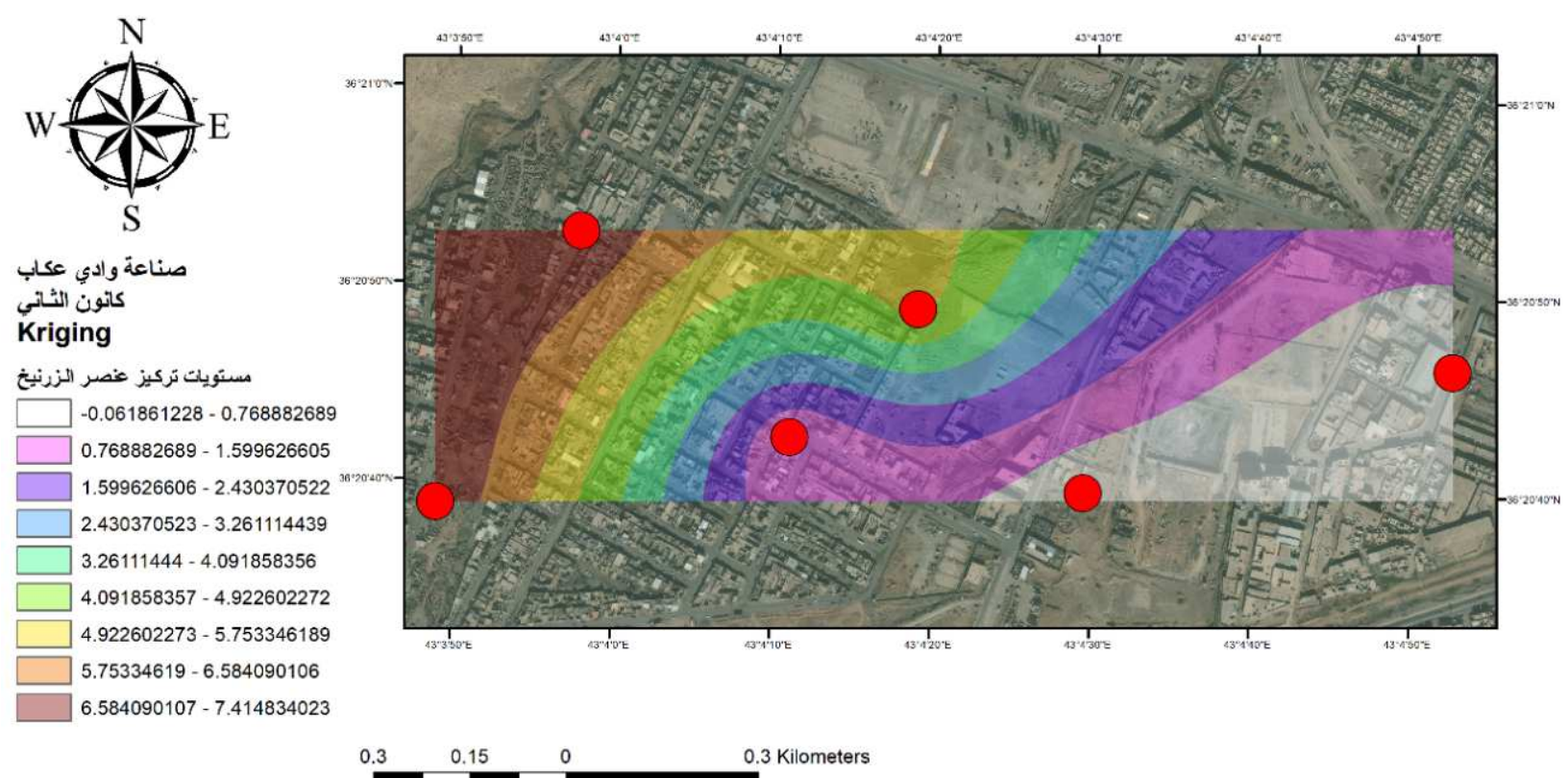

Figure 5. Shows the distribution of Arsenic in the soil of the Okab industry.

\section{Cadmium (Cd)}

Cadmium is a metal that has the potential to be seen on the surface of the spectral surface, including the montmorillonite, which has many heavy elements, including cadmium. [7]

The results in a table 1 showed that the Cadmium metal values in the soil of the Al- karama Industry ranged between $(0.02-0.06)$ ppm. The maps obtained by GIS10.6.1 show the distribution of the cadmium component in the surface of the Karama Industry Area Figure 6. Maps show a clear increase in cadmium in areas near the plastic recycling plant that are cadmium waste. According to who manual WHO. 2003 the presence of the cadmium metal in this area is below the permitted limit where the evidence indicates that the allowable concentration is (1-3) ppm.
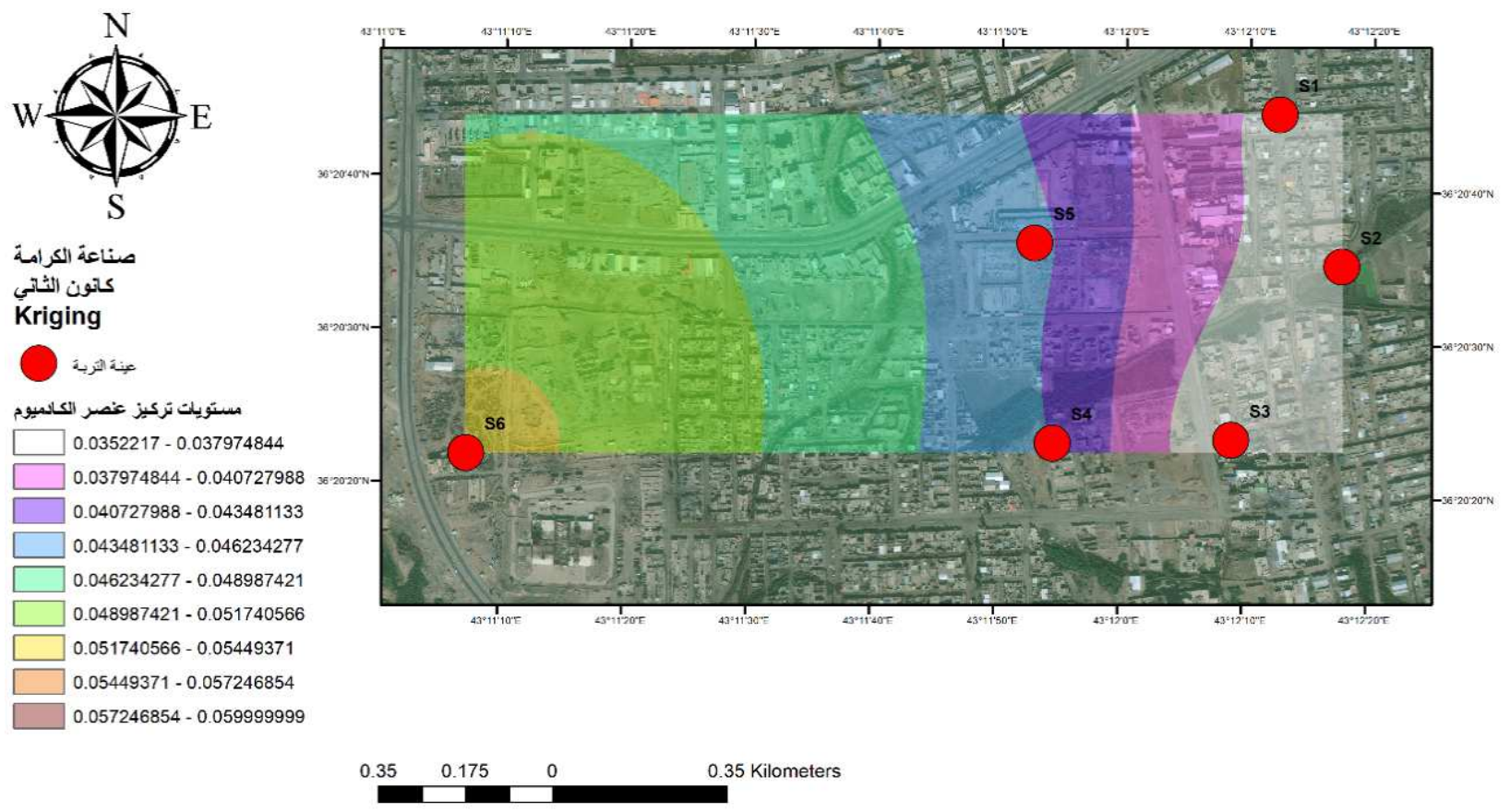

Figure 6. Shows the distribution of Cadmium in the soil of the Al-karama industry.

The results in a table 2 showed that the Cadmium metal values in the soil of the Okab Industry ranged between $(0$

\section{$0.03) \mathrm{ppm}$}

The maps obtained by GIS10.6.1 show the distribution of 
the cadmium metal in the surface of the Okab Industry Area Figure 7. Maps show a clear increase in cadmium in areas close to tanning workshops and car batteries. According to the who, 2003 Guide on the permissible limit of the cadmium metal, it is crossing less than the permitted limit of (1-3) ppm.

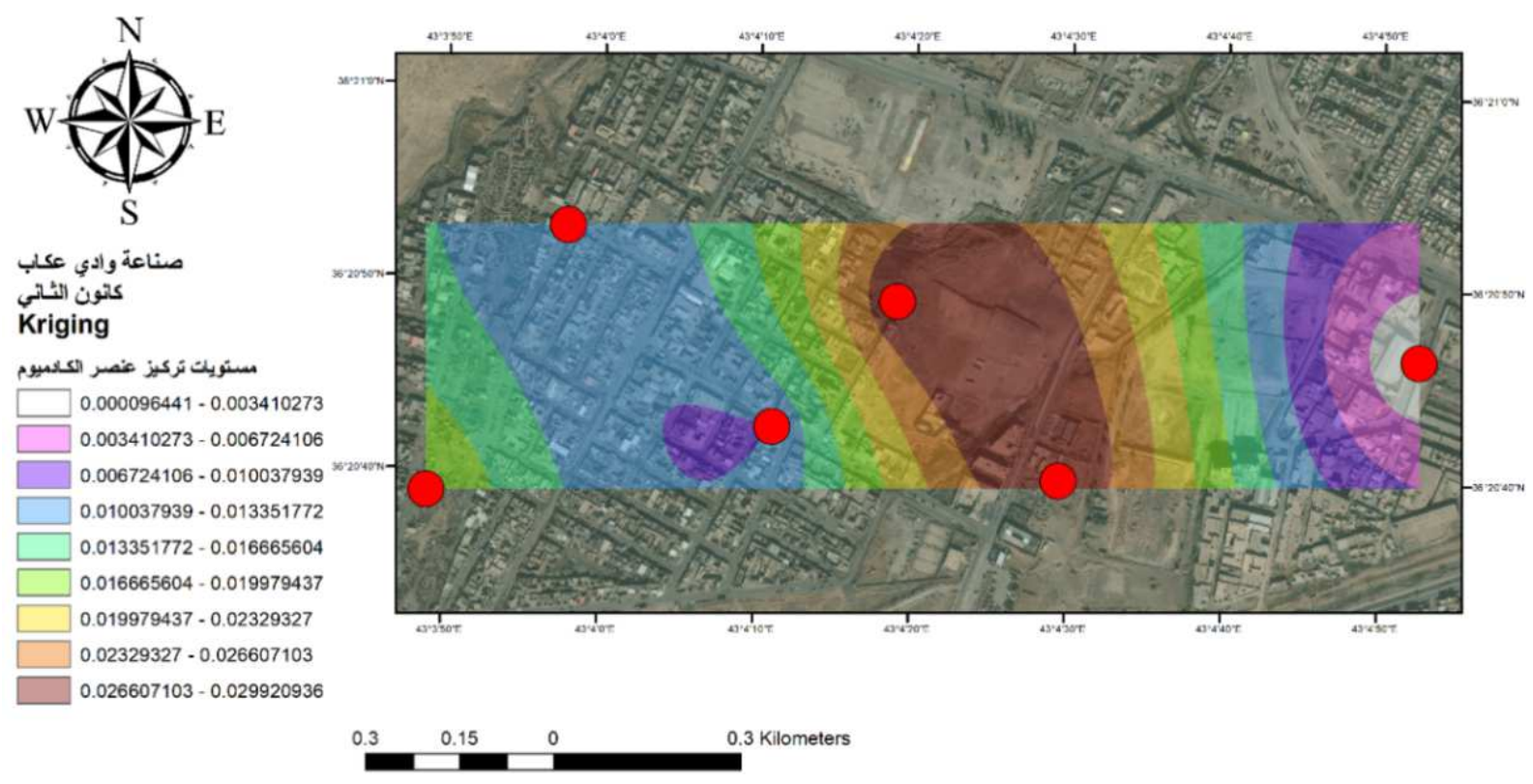

Figure 7. Shows the distribution of Cadmium in the soil of the Okab industry.

\section{Nickel (Ni)}

The nickel metal is characterized by its presence in various types of soil, where the barricades vary between arid and semi-arid regions and between tropical regions and have the highest concentration in base-superior rocks such limestone. [3]

The results in a table 1 showed that the Nickel metal values in the soil of the Al- karama Industry ranged between
(117.33 - 217.40) ppm. The maps obtained by GIS10.6.1 show the distribution of the nickel metal in the surface of the Karama Industry Area Figure 8. Maps show a clear increase in nickel in areas close to accumulated industrial waste. According to who's Guide who, 2003 the nickel component presence is considered contaminated in this area where it exceeded the limit, where the evidence indicated that the allowable concentration is (30-75) ppm.
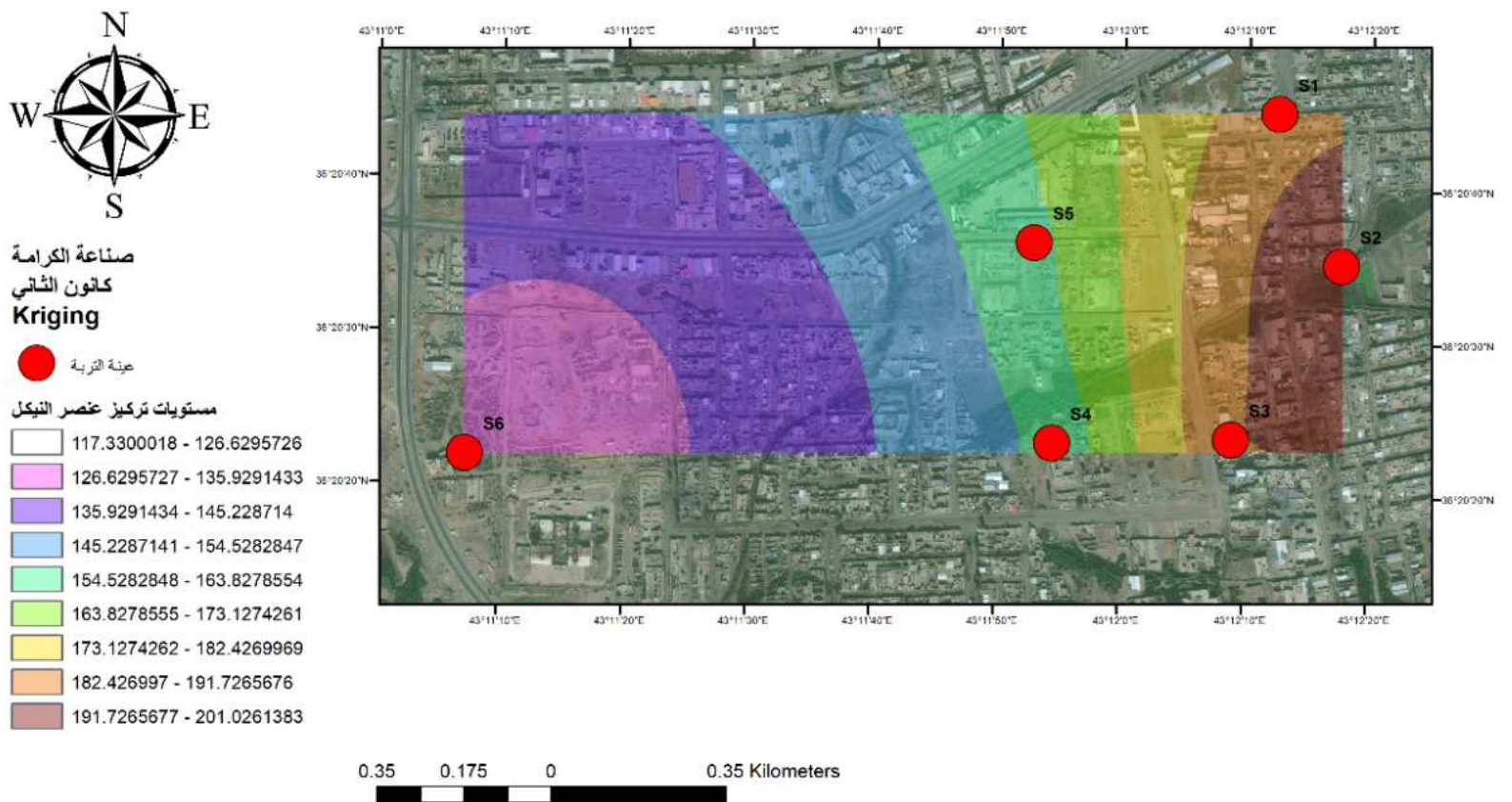

Figure 8. Shows the distribution of Nickel in the soil of the Al-karama industry.

The results in a table 2 showed that the Nickel element values in the soil of the Okab Industry ranged between $(90.65$
- 227.34) ppm

The maps obtained by GIS10.6.1 show the distribution of 
the nickel metal in the surface of the Okab Industry Area Figure 9. Maps show a clear increase in nickel in areas close to industrial area waste. According to the WHO, 2003 Guide on the limit allowed for the nickel metal in the soils, it is considered contaminated to approach this area where the permitted values (30-75) per ppm are exceeded.
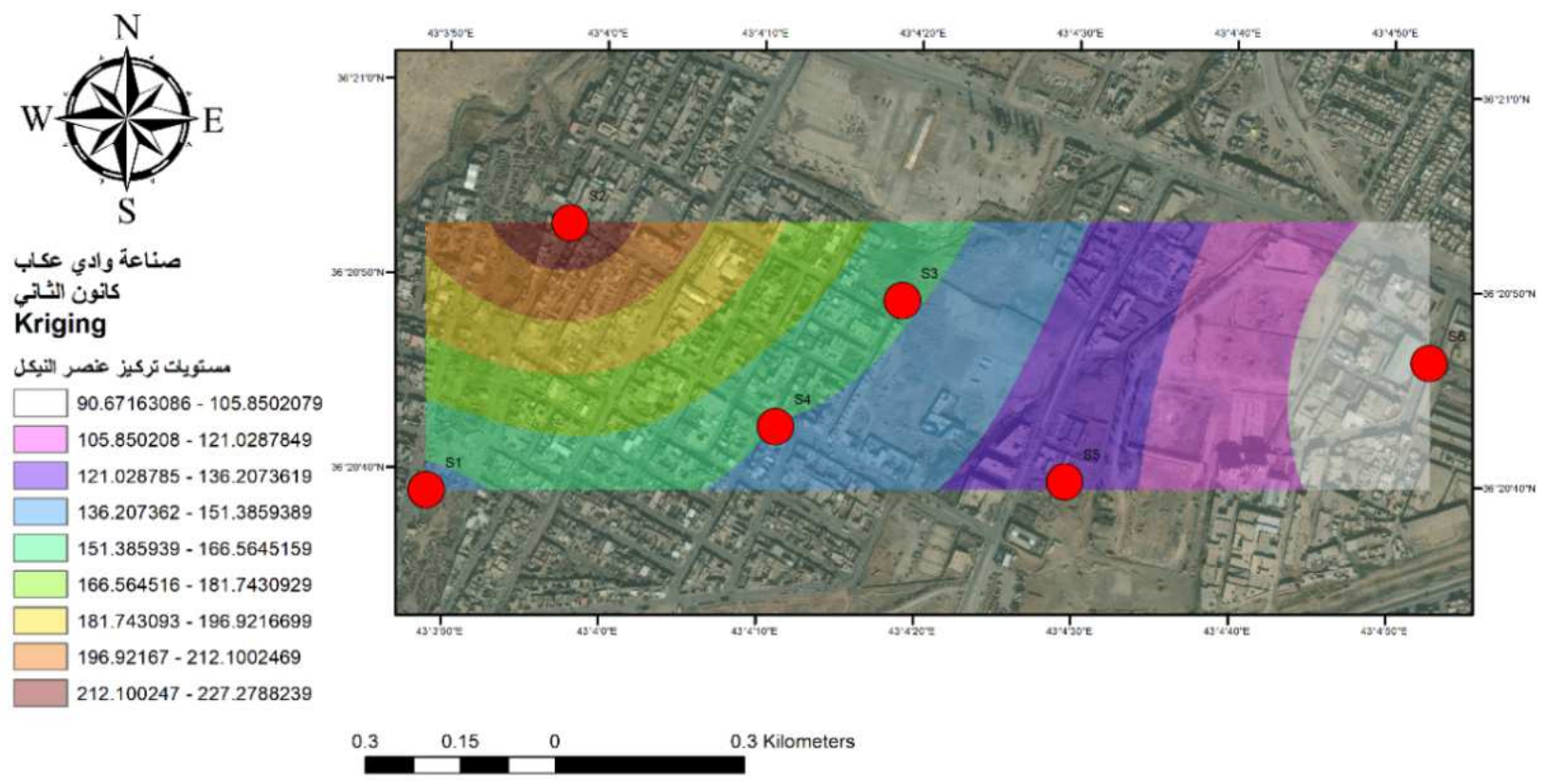

Figure 9. Shows the distribution of Nickel in the soil of the Okab industry.

\section{Chromium (Cr)}

The presence of the Chromium metal depends on the nature and type of the original rock generated for which it is abundant in most rocks of Earth's crust, and there are varying concentrations in different types of rock. In volcanic rocks, its concentration (200-300) ppm and in acidic rocks is concentrated (20-40) ppm.

The results in a table 1 showed that the values of the Chromium metal in the soil of the Karama Industry ranged between $(43.30-54.40)$ ppm.

The maps obtained by GIS10.6.1 show the distribution of the Chromium component of the surface in the Karama Industry Area Figure 10. Maps show a clear increase in the Chromium component in areas close to car tanning shops. According to WHO Guide 2003 the presence of the Chromium component is considered contaminated in this area where it exceeds the limit, where the evidence indicates that the allowable concentration is (1-5) ppm.

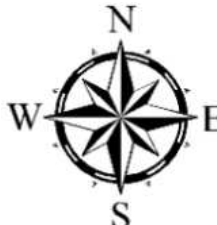

$\mathrm{S}$

صناعة الكرافة

Kriging

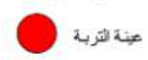

مصنويات تركيز غنصر الكروم

43.3088913 - 44.53955756

$44.53955757-45.77022383$ $45.77022384-47.0008901$ $47.00089011-48.23155636$ 48.23155637 - 49.46222263 $49.46222264-50.6928889$ $50.69288891-51.92355516$ $51.92355517-53.15422143$ $53.15422144 \cdot 54.3848877$
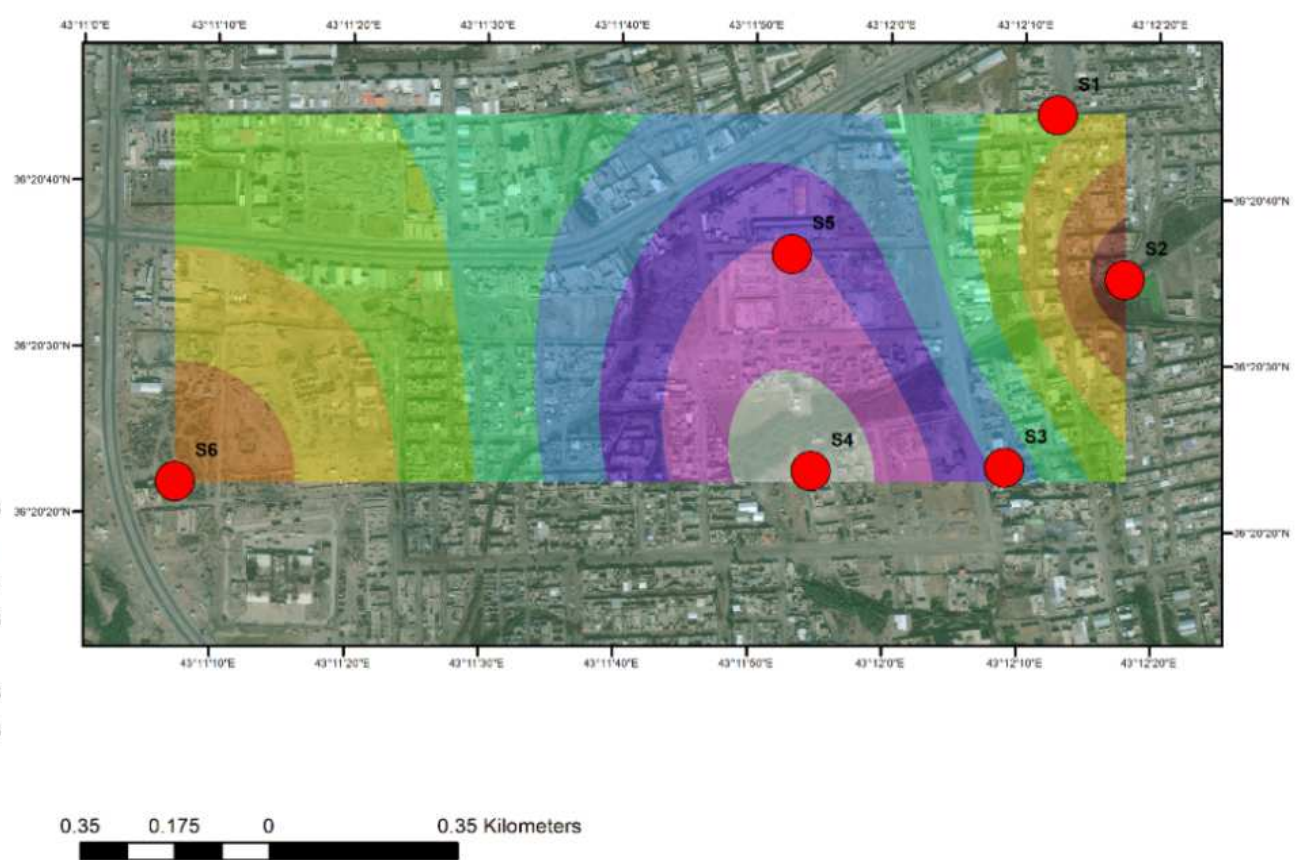

Figure 10. Shows the distribution of Chromium in the soil of the AL-karama industry. 
The results in a table 2 showed that the Chromium metal values in the soil of the Okab Industry ranged between $(77.32$ $-288.21) \mathrm{ppm}$.

The maps obtained by GIS10.6.1 show the distribution of the Chromium metal in the surface of the Okab Industry Area Figure 11. Maps show a clear increase in the Chromium component in areas close to the industrial zone's waste. According to the WHO, 2003 Guide on the permitted limit for the Chromium metal in the soils, it is considered contaminated soil in this area where the permitted values (15) per ppm are exceeded.
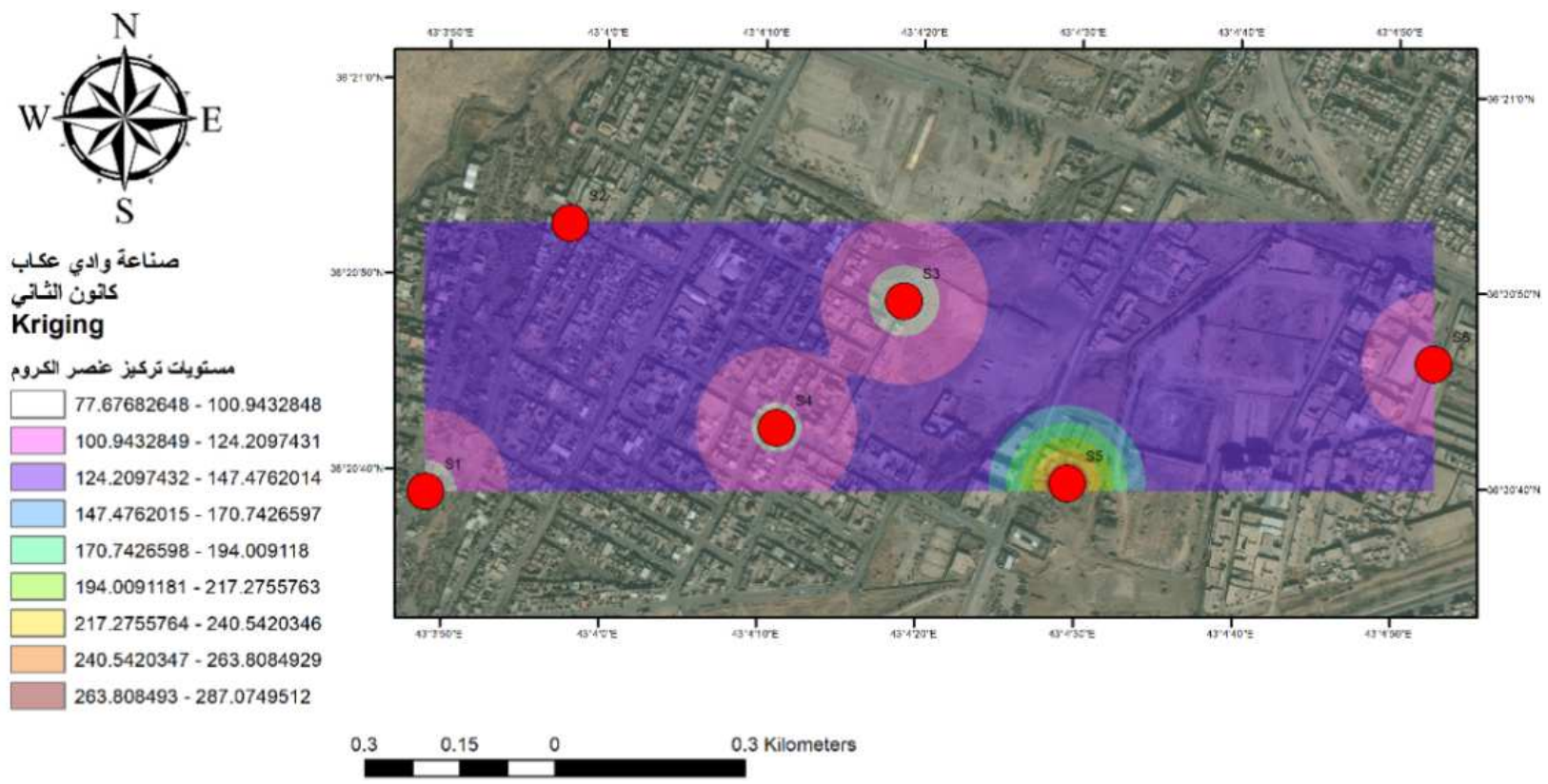

Figure 11. Shows the distribution of Chromium in the soil of the Okab industry.

\section{Conclusions}

The results obtained for heavy metals and compared to the WHO, 2003 manual and by monitoring their distribution using the ArcMap GIS software show that these areas are already contaminated with $(\mathrm{Ni}, \mathrm{Cr}$, As) metals that have Exceeded the specified values. In addition, $\mathrm{Pb}$ and $\mathrm{Cd}$ elements are within the allowed values.

\section{References}

[1] Abdolhossein Parazanganeh, Pooya Hajisoltani, Abbasali Zamani, 2010, Assessment of heavy metal pollution in surficial soils surrounding Zinc Industrial Complex in Zanjan -Iran, Faculty of Science, Zanjan University.

[2] Adepoju-Bello AA, Alabi OM (2005)." Heavy metals", A review. The Nig J. Pharm., 37: 41-45.

[3] Aubert H. \& Pinta M, (1977). Trace Elements in Soils, Developments in Soil Science 7, Wlsevier Scientific Publishing company, Amesterdam, 395p.

[4] Bing Chen, Ariel F. Stein, Pabla Guerrero Maldonado, Sanchez de la Campa, Yolanda Gonzalez-Castanedo, Nuria Castell, Jesus D. dela Rosa 2013, size distribution and concentration of heavy metals in atmospheric aerosols originating from industrial emissions as predicted by the HYSPLIT model, center for research in sustainable Chemistry, University of Huelva.
[5] Carlin DJ, Naujokas MF, Bradham KD, Cowden J, Heacock M, Henry HF, Lee JS, Thomas DJ, Thompson C, Tokar EJ, Waalkes MP, Birnbaum LS, Suk WA,. (2016)Arsenic and Environmental Health: State of the Science and Future Research Opportunities. Environ. Health Perspect. 2016 Jul; 124 (7): 890-9.

[6] [ Chakraborti D, Hussain A, Allauddin M (2003)."Arsenic: Environmental and health aspects with special reference to ground water in South Asia", Journal of Environmental Science and Health, Part A: Toxic Hazard Substance Environmental Engineering; 38: 11-15.

[7] Drever J. I., (1997), Water - Wells in implementation mainterdation, Habib, R. Habib and others, 2012. Toxic Heavy Metals in Soil and Some Plants in Baghdad, Iraq, Journal of Al-Nahrain University, Science, Vol. 15 (2), June, pp. 1-16.

[8] Hussain, I. and L. Khan (2010)." Comparative study on heavy metal contents in Taraxacum officinale Int. J. Pharmacognosy and Phytochemical Res. 2 (1): 15-18.

[9] Jingliang Mei, Zhichun Li, Linhua Sun, Herong Gui Xingming Wang, 2011, Assessment of Heavy Metals in the Urban River Sediments in Suzhou City, Northern Anhua Province, china, School of Earth Environment, Anhui University of Science and Technology Huainan, School of Erath Science and Engineering, Suzhou University Suzhou, China.

[10] Keller E. A., (1976). environmental Geology, 488p. Bell Howell Co. Columbus, Ohio.

[11] Lone, I. M.; Stoffella, J. P. and Yang, X (2008). "Phytoremediation of Heavy Metal Polluted Soils and Water", Progresses and Perspectives. Journal of Zhejiang University Science, 9 (3): 210-220 
[12] M. chakravarty and A. D. patgiri, 2009. determined assessment pollution of Dikrong river sediment, Atmospheric Environment, ElsevOier journal J Hum Ecol, 27 (1): 63-67. maintenance \& restoration, John Wiley \& Sons, London, 379P.

[13] Okrent, D. (1999)."An intergenerational equity and its clash with interagenerationalequity and on the nead for policies to guide the regulation of disposal of wastes and other activities posing very long time risks", Risk Analysis, 19: 877-901.

[14] Rahimi, M.; Farhadi, R. and Balashahri, S. M (2012)." Effects of Heavy Metals on The Medicinal Plant", International Journal of Agronomy and Plant Production, 3 (4): 154-158
[15] Sayadi MH, Rezaei MR, (2014) Impact of land use on the distribution of toxic metals in surface soils in Birjand city, Iran. Proceedings of the International Academy of Ecology and Environmental Sciences, 4, 18-29.

[16] Sonayei Y., Ismail N. and Talebi S. (2009)." Determination of heavy metals in Zayandeh Road River, Isfahan-Iran, Wor", Appl. Sci. J. 1., 6, 1204-1214.

[17] World Health Organization (WHO). (2003). International standards for soil. 